\title{
Attitude, Social Presence, and Satisfaction of Dental Students toward E-Learning - A Cross-Sectional Study from Haryana, India
}

\author{
Shakila Mahesh ${ }^{1}$, Savita Bansal2 ${ }^{2}$, Kruthiventi Hemalata ${ }^{3}$, Anila Maria Varghese ${ }^{4}$ \\ 1, 2, 3, 4 Department of Microbiology, Manav Rachna International \\ Institute of Research and Studies, Faridabad, Haryana, India.
}

\section{ABSTRACT}

\section{BACKGROUND}

As the epidemic of corona virus disease - 19 (COVID - 19) has struck the entire world, schools and colleges had to shut, there was a sudden shift from in-person education to online education which became difficult for the institutions. There was a distinctive rise of e-learning and this method of learning has several amazing features that would be useful for use during this period as this will constitute a new and fantasizing method of learning for the students

\section{METHODS}

This is a cross-sectional study. The study participants were the students from dental college in Faridabad from $1^{\text {st }}$ year to the final year of under graduate (UG) program. The total number of participants were 340 students. An online questionnaire was designed and given to students through the platform, google forms. This questionnaire consisted of three parameters - attitude, social presence, and student satisfaction.

\section{RESULTS}

Among the 340 students, $40 \%$ of the students were males and $60 \%$ of them were females. The three domains measured attitude, social presence, and satisfaction; to elearning had fourteen, seven and nine questions respectively. Pearson's correlation test was applied, $\mathrm{P}$ - value was significant at $\mathrm{P}<0.05$. When the three perspectives of e-learning were correlated with e-learners using pearson's correlation coefficient, it was found that there was a very strong positive correlation among these three domains ( $\mathrm{P}=0.0001$ for all three perspectives).The correlation between the three perspectives of e-learning, attitude versus social presence was 0.773 , attitude versus satisfaction was 0.756 and social presence versus satisfaction was 0.794 .

\section{CONCLUSIONS}

A predominantly positive response has been observed for satisfaction aspect. The results showed a positive response as it was seen in other surveys. When it comes to the social presence, the study shows that the online setting becomes impersonal but the comfort in collaboration is better than offline model.

\section{KEY WORDS}

Learning, COVID - 19 Pandemic, Attitude, Satisfaction, Social Presence, Dental Students
Corresponding Author: Dr. Shakila Mahesh, HOD, Microbiology, FDS, MRIIRS, Faridabad, Haryana - 121001, India.

E-mail: shakila.mrdc@mrei.ac.in

DOI: $10.14260 / j e m d s / 2021 / 557$

How to Cite This Article:

Mahesh S, Bansal S, Hemalata $K$, et al. "Attitude, social presence, and satisfaction of dental students towards E-learning - a cross-sectional study from Haryana, India". J Evolution Med Dent Sci 2021;10(33): 2728-2733, DOI:

$10.14260 /$ jemds/2021/557

Submission 15-03-2021, Peer Review 11-06-2021, Acceptance 19-06-2021, Published 16-08-2021.

Copyright (C) 2021 Shakila Mahesh et al. This is an open access article distributed under Creative Commons Attribution License [Attribution 4.0 International (CC BY 4.0)] 


\section{BACKGROUND}

The academic calendar in many universities have tousled into a state of disorder by the COVID-19 pandemic globally. UNESCO Director, General Audrey Azoulay mentioned that they had never witnessed educational disruption on such a massive scale. ${ }^{1}$ The COVID-19 pandemic has led to university closure among 61 countries in Africa, Asia, Europe, the Middle East, North America, and South America. ${ }^{2}$ The worldwide closures have impacted more than 1.2 billion children in 186 countries at different points in their COVID - 19 infection rates. Currently universities are focused on ensuring academic continuity for students through E-learning platform, and in many cases have relied on existing online courses. ${ }^{3}$

Educational institutions in the world which were unwilling to modify, are now evolving and turning into completely digitalized, comprehending the urgent need of this present circumstances. Groundbreaking solution can only help us deal with the pandemic. ${ }^{4}$ Top universities in the world such as Tsinghua, Peking University, Harvard, MIT, Yale, Oxford, Cambridge, among others are moving in this direction. ${ }^{2,5}$

The e-learning system is user-friendly, and students will be engaged in learning activities with teachers from their home, thus keeping their minds busy. The future of college is online, and it is cheaper. There are numerous factors that influence the efficacy of online learning, such as social communication, academic competences, administrative problems, technical expertise, time and assistance for studies, student enthusiasm, experiencing technical difficulties, downloading errors, login troubles, installation issues, problems with audio and video, and the ability to access the internet. ${ }^{7}$

The learning process cannot reach its full potential until students practice what they learn. Sometimes, online content is all theoretical and does not let students practice and learn effectively. Mediocre course content is also a major issue. Students feel that lack of community, technical problems, and difficulties in understanding instructional goals are the major barriers for online learning. ${ }^{8}$

Educational institutions should evaluate such issues and create a robust online platform. The instructors can record and present the material and also ensure that the students have access to these materials through a laptop/tablet or a good smart phone, if not then they are stuck. ${ }^{9}$

Teachers need to set time boundaries and notices for students to make them alert and considerate. Online courses should be structured in such a way that they are relevant, student-centered, lively and innovative. ${ }^{10}$ Teachers have been asked to become both artists and grasp new technologies and tools to teach fluently. ${ }^{11,12}$

Several dental colleges have been locked down due to the pandemic. ${ }^{13}$ Majority of the lectures have switched to the online mode. Dental education is primarily composed of three components: The first is the theory sessions, second is the laboratory sessions and the third one is the clinical practice in the field. The theory classes can be easily switched to online mode. There are several different methods available on the web such as: Google Meet, Microsoft Teams, Zoom Meetings and many more. Virtual reality (VR) techniques can be the best methods which can be used during this period, but we do not have such advanced facilities available. Laboratory sessions need interaction between teacher and student and clinical practice is the most significant foundation of dental education and during this there will be close communication between the intern doctor and the patient. This will be the most difficult thing during the pandemic. ${ }^{13}$

\section{METHODS}

This is a cross-sectional study. The survey was conducted online to students of Manav Rachna Dental College through the platform, Google Forms. The study period was for 7 months, from June 2021 to December 2021. An online questionnaire was designed based on earlier publications on online studies.14,15,16 This questionnaire consisted of three parameters - attitude, social presence, and student satisfaction. The questionnaire consisted of 14 attitude based questions on user friendliness, like the idea of e-learning, convenience and comfort and 7 questions on social presence, such as to assess being anonymous with the instructor to face to face presence, interaction with the instructor, exciting and looking forward to online classes, the third parameter was 9 questions based on satisfaction, which included instructors support, quality of delivery, learning resources, IT tools, assessment methods. In the questionnaire, participants had the option to agree or disagree using the five-point Likert scale. The ethical clearance certificate was provided for the study. The online google form survey is participation of the students based on their willingness.

\section{Participants}

The study participants are the students from Manav Rachna Dental College from $1^{\text {st }}$ year to the final year of UG program. The total number of students were 340 , among them 87 students were from first year, 84 each from second and third year and 85 students from final year.

\section{Statistical Analysis}

The responses were carefully collected in Microsoft Excel sheets and were statistically analyzed. The scores of the three parameters were calculated and were presented as mean score separately. There was a correlation done between the three perspectives of e-learning using Pearson's correlation coefficient.

\section{RESULTS}

This study was conducted on dental students with a population of 340 . Among them, $40 \%$ of the students were males and $60 \%$ of them were females. The three domains measured were attitude, social presence, and satisfaction to elearning which had fourteen, seven and nine questions respectively.

\section{Attitude Based Questions}

The responses to attitude-based questions are demonstrated in Table 1. The attitude of the participants was assessed using 14 questions on a 5-point Likert scale. The scale ranged from disagree $^{1}$ to strongly agree. ${ }^{5}$ 


\begin{tabular}{|c|c|c|c|c|c|}
\hline Question & Strongly Disagree & Disagree & Not Sure & Agree & Strongly Agree \\
\hline E - learning is user friendly and easy to find information & $\begin{array}{c}10 \\
2.9 \%\end{array}$ & $\begin{array}{c}15 \\
4.4 \%\end{array}$ & $\begin{array}{c}34 \\
10 \%\end{array}$ & $\begin{array}{c}193 \\
56.8 \%\end{array}$ & $\begin{array}{c}88 \\
25.9 \%\end{array}$ \\
\hline Like the idea of e-learning & $\begin{array}{c}10 \\
2.9 \%\end{array}$ & $\begin{array}{c}25 \\
7.4 \%\end{array}$ & $\begin{array}{c}35 \\
10.3 \%\end{array}$ & $\begin{array}{c}191 \\
56.2 \%\end{array}$ & $\begin{array}{c}79 \\
23.2 \%\end{array}$ \\
\hline E-learning is an innovative concept and must be encouraged & $\begin{array}{c}12 \\
3.5 \%\end{array}$ & $\begin{array}{c}16 \\
4.7 \%\end{array}$ & $\begin{array}{c}47 \\
13.8 \%\end{array}$ & $\begin{array}{c}180 \\
52.9 \%\end{array}$ & $\begin{array}{c}85 \\
25 \%\end{array}$ \\
\hline $\begin{array}{l}\text { E-learning platform is an innovative concept, fun to use and } \\
\text { should be encouraged }\end{array}$ & $\begin{array}{c}10 \\
2.9 \%\end{array}$ & $\begin{array}{c}24 \\
7.1 \%\end{array}$ & $\begin{array}{c}51 \\
15.0 \%\end{array}$ & $\begin{array}{c}176 \\
51.8 \%\end{array}$ & $\begin{array}{c}79 \\
23.2 \%\end{array}$ \\
\hline $\begin{array}{c}\text { E-learning enables us to study at our own pace and at a time } \\
\text { convenient }\end{array}$ & $\begin{array}{c}10 \\
2.9 \%\end{array}$ & $\begin{array}{c}24 \\
7.1 \%\end{array}$ & $\begin{array}{c}39 \\
11.4 \%\end{array}$ & $\begin{array}{c}187 \\
55 \%\end{array}$ & $\begin{array}{c}80 \\
23.5 \%\end{array}$ \\
\hline $\begin{array}{c}\text { E-learning is more comfortable to use than face to face } \\
\text { interaction. }\end{array}$ & $\begin{array}{c}24 \\
7.1 \%\end{array}$ & $\begin{array}{c}74 \\
21.8 \%\end{array}$ & $\begin{array}{c}54 \\
15.9 \%\end{array}$ & $\begin{array}{c}122 \\
35.9 \%\end{array}$ & $\begin{array}{c}66 \\
19.4 \%\end{array}$ \\
\hline $\begin{array}{l}\text { E-learning is easy to use and communicate than face to face } \\
\text { interaction. }\end{array}$ & $\begin{array}{c}17 \\
5 \%\end{array}$ & $\begin{array}{c}74 \\
21.8 \%\end{array}$ & $\begin{array}{c}56 \\
16.5 \%\end{array}$ & $\begin{array}{c}130 \\
38.2 \%\end{array}$ & $\begin{array}{c}63 \\
18.5 \%\end{array}$ \\
\hline $\begin{array}{l}\text { E-learning has technical issues of slow or unresponsive internet } \\
\text { connectivity }\end{array}$ & $\begin{array}{c}10 \\
2.9 \%\end{array}$ & $\begin{array}{c}15 \\
4.4 \%\end{array}$ & $\begin{array}{c}40 \\
11.7 \%\end{array}$ & $\begin{array}{c}158 \\
46.5 \%\end{array}$ & $\begin{array}{c}117 \\
34.4 \%\end{array}$ \\
\hline $\begin{array}{l}\text { Prefer classroom based learning to know the identity of } \\
\text { instructors }\end{array}$ & $\begin{array}{c}13 \\
3.8 \%\end{array}$ & $\begin{array}{c}40 \\
11.8 \%\end{array}$ & $\begin{array}{c}80 \\
23.5 \%\end{array}$ & $\begin{array}{c}141 \\
41.5 \%\end{array}$ & $\begin{array}{c}66 \\
19.4 \%\end{array}$ \\
\hline $\begin{array}{l}\text { Have you ever been assessed on your personal online learning } \\
\text { skills and abilities before the start of an e-learning course? }\end{array}$ & $\begin{array}{l}\text { Always } \\
12 \\
3.5 \%\end{array}$ & $\begin{array}{l}\text { Never } \\
77 \\
22.6 \%\end{array}$ & $\begin{array}{l}\text { Often } \\
38 \\
11.2 \%\end{array}$ & $\begin{array}{l}\text { Rarely } \\
92 \\
27.1 \%\end{array}$ & $\begin{array}{l}\text { Sometimes } \\
121 \\
35.6 \%\end{array}$ \\
\hline E-learning is worth my time. & $\begin{array}{l}12 \\
3.5 \%\end{array}$ & $\begin{array}{l}21 \\
6.2 \%\end{array}$ & $\begin{array}{l}85 \\
25 \%\end{array}$ & $\begin{array}{l}170 \\
50 \%\end{array}$ & $\begin{array}{c}52 \\
15.3 \%\end{array}$ \\
\hline E-learning is stimulating and exciting. & $\begin{array}{c}14 \\
4.1 \%\end{array}$ & $\begin{array}{c}34 \\
10 \%\end{array}$ & $\begin{array}{c}69 \\
20.3 \%\end{array}$ & $\begin{array}{c}169 \\
49.7 \%\end{array}$ & $\begin{array}{c}54 \\
15.9 \%\end{array}$ \\
\hline $\begin{array}{c}\text { Participation and contributions in course activities, consulting } \\
\text { provided material and perceiving progress is better in e-learning } \\
\text { than classroom learning }\end{array}$ & $\begin{array}{c}22 \\
6.5 \%\end{array}$ & $\begin{array}{c}50 \\
14.7 \%\end{array}$ & $\begin{array}{c}77 \\
22.6 \%\end{array}$ & $\begin{array}{c}139 \\
40.9 \%\end{array}$ & $\begin{array}{c}52 \\
15.3 \%\end{array}$ \\
\hline I enjoy and look forward to e-learning classes. & $\begin{array}{c}21 \\
6.2 \%\end{array}$ & $\begin{array}{c}33 \\
9.7 \%\end{array}$ & $\begin{array}{c}63 \\
18.5 \%\end{array}$ & $\begin{array}{c}165 \\
48.5 \%\end{array}$ & $\begin{array}{c}58 \\
17.1 \%\end{array}$ \\
\hline
\end{tabular}

\begin{tabular}{|c|c|c|c|c|c|}
\hline Question & Strongly Disagree & Disagree & Not Sure & Agree & Strongly Agree \\
\hline The instructor facilitates discussions in the online class. & $\begin{array}{l}8 \\
2.4 \%\end{array}$ & $\begin{array}{l}14 \\
4.1 \%\end{array}$ & $\begin{array}{c}44 \\
12.9 \%\end{array}$ & $\begin{array}{c}195 \\
57.4 \%\end{array}$ & $\begin{array}{l}79 \\
23.2 \%\end{array}$ \\
\hline $\begin{array}{c}\text { I feel more comfortable interacting with other participants in } \\
\text { online learning. }\end{array}$ & $\begin{array}{l}18 \\
5.3 \%\end{array}$ & $\begin{array}{c}48 \\
14.1 \%\end{array}$ & $\begin{array}{c}76 \\
22.3 \%\end{array}$ & $\begin{array}{c}139 \\
40.9 \%\end{array}$ & $\begin{array}{c}59 \\
17.4 \%\end{array}$ \\
\hline $\begin{array}{l}\text { Computer-mediated communication is an excellent medium for } \\
\text { social interaction }\end{array}$ & $\begin{array}{l}15 \\
4.4 \%\end{array}$ & $\begin{array}{l}33 \\
9.7 \%\end{array}$ & $\begin{array}{c}67 \\
19.7 \%\end{array}$ & $\begin{array}{c}162 \\
47.6 \%\end{array}$ & $\begin{array}{c}63 \\
18.5 \%\end{array}$ \\
\hline The instructor creates a feeling of an online community. & $\begin{array}{c}6 \\
1.8 \%\end{array}$ & $\begin{array}{c}24 \\
7.1 \%\end{array}$ & $\begin{array}{c}56 \\
16.5 \%\end{array}$ & $\begin{array}{c}191 \\
56.2 \%\end{array}$ & $\begin{array}{c}63 \\
18.5 \%\end{array}$ \\
\hline $\begin{array}{l}\text { Discussions using the medium of computer-mediated } \\
\text { communication tend to be more impersonal than face to face } \\
\text { discussions. }\end{array}$ & $\begin{array}{c}10 \\
2.9 \%\end{array}$ & $\begin{array}{c}36 \\
10.6 \%\end{array}$ & $\begin{array}{c}80 \\
23.6 \%\end{array}$ & $\begin{array}{c}158 \\
46.5 \%\end{array}$ & $\begin{array}{c}56 \\
16.5 \%\end{array}$ \\
\hline $\begin{array}{l}\text { My point of view is better acknowledged by other participants in } \\
\text { the online class }\end{array}$ & $\begin{array}{c}8 \\
2.4 \%\end{array}$ & $\begin{array}{c}43 \\
12.6 \%\end{array}$ & $\begin{array}{c}98 \\
28.9 \%\end{array}$ & $\begin{array}{c}145 \\
42.6 \%\end{array}$ & $\begin{array}{c}46 \\
13.5 \%\end{array}$ \\
\hline I feel more comfortable introducing myself in the online class & $\begin{array}{c}6 \\
1.8 \%\end{array}$ & $\begin{array}{c}43 \\
12.6 \%\end{array}$ & $\begin{array}{c}72 \\
21.2 \%\end{array}$ & $\begin{array}{c}169 \\
49.7 \%\end{array}$ & $\begin{array}{c}50 \\
14.7 \%\end{array}$ \\
\hline
\end{tabular}

\begin{tabular}{|c|c|c|c|c|c|}
\hline Question & Strongly Disagree & Disagree & Not Sure & Agree & Strongly Agree \\
\hline I am satisfied with the online teaching program. & $\begin{array}{c}16 \\
4.7 \%\end{array}$ & $\begin{array}{c}37 \\
10.9 \%\end{array}$ & $\begin{array}{c}54 \\
15.9 \%\end{array}$ & $52.4 \%$ & $\begin{array}{c}55 \\
16.2 \%\end{array}$ \\
\hline $\begin{array}{l}\text { I am satisfied with the "Instructor Support" teacher who provides } \\
\text { guidance and mentoring the students. }\end{array}$ & $\begin{array}{c}5 \\
1.5 \%\end{array}$ & $\begin{array}{l}18 \\
5.3 \%\end{array}$ & $\begin{array}{c}39 \\
11.4 \%\end{array}$ & $\begin{array}{l}206 \\
60.6 \%\end{array}$ & $\begin{array}{c}72 \\
21.2 \%\end{array}$ \\
\hline I am satisfied with the "E-learning environment" & $\begin{array}{l}11 \\
3.2 \%\end{array}$ & $\begin{array}{l}33 \\
9.7 \%\end{array}$ & $\begin{array}{c}57 \\
16.8 \%\end{array}$ & $\begin{array}{c}185 \\
54.4 \%\end{array}$ & $\begin{array}{c}54 \\
15.9 \%\end{array}$ \\
\hline I am satisfied with the "Learning Resources" available? & $\begin{array}{c}6 \\
1.8 \%\end{array}$ & $\begin{array}{l}33 \\
9.7 \%\end{array}$ & $\begin{array}{c}54 \\
15.9 \%\end{array}$ & $\begin{array}{c}188 \\
55.3 \%\end{array}$ & $\begin{array}{c}59 \\
17.4 \%\end{array}$ \\
\hline $\begin{array}{l}\text { I am satisfied with the "Quality of Delivery" of lectures in attaining } \\
\text { the interest and stimulating learning among students }\end{array}$ & $\begin{array}{c}8 \\
2.4 \%\end{array}$ & $\begin{array}{l}31 \\
9.1 \%\end{array}$ & $\begin{array}{c}44 \\
13 \%\end{array}$ & $\begin{array}{c}195 \\
57.4 \%\end{array}$ & $\begin{array}{c}62 \\
18.2 \%\end{array}$ \\
\hline I am satisfied with the “Content and Organization' in E-learning & $\begin{array}{c}7 \\
2.1 \%\end{array}$ & $\begin{array}{l}27 \\
7.9 \%\end{array}$ & $\begin{array}{c}42 \\
12.3 \%\end{array}$ & $\begin{array}{c}202 \\
59.4 \%\end{array}$ & $\begin{array}{c}62 \\
18.2 \%\end{array}$ \\
\hline $\begin{array}{c}\text { I am satisfied with the "Assessment" mechanism in E-learning } \\
\text { which include assignments, quizzes, graded discussions and term } \\
\text { exam? }\end{array}$ & $\begin{array}{c}9 \\
2.6 \%\end{array}$ & $\begin{array}{c}31 \\
9.1 \%\end{array}$ & $\begin{array}{c}40 \\
11.7 \%\end{array}$ & $\begin{array}{c}198 \\
58.2 \%\end{array}$ & $\begin{array}{c}62 \\
18.2 \%\end{array}$ \\
\hline I am satisfied with online tutorials/remedial classes & $\begin{array}{c}7 \\
2.1 \%\end{array}$ & $\begin{array}{c}25 \\
7.4 \%\end{array}$ & $\begin{array}{c}64 \\
18.8 \%\end{array}$ & $\begin{array}{c}181 \\
53.2 \%\end{array}$ & $\begin{array}{c}63 \\
18.5 \%\end{array}$ \\
\hline $\begin{array}{l}\text { I am satisfied and comfortable using information technology (IT) } \\
\text { tools for attaching files, chatting, downloading and posting } \\
\text { messages? }\end{array}$ & $\begin{array}{c}6 \\
1.8 \%\end{array}$ & $\begin{array}{c}28 \\
8.2 \%\end{array}$ & $\begin{array}{c}41 \\
12 \%\end{array}$ & $\begin{array}{l}199 \\
58.5 \%\end{array}$ & $\begin{array}{c}66 \\
19.4 \%\end{array}$ \\
\hline
\end{tabular}

A positive response, $56.8 \%$ agree, $25.9 \%$ strongly agree, was observed with regards to e-learning being a user-friendly technique. More than half of the respondents liked the idea of e-learning, $56.2 \%$ agreed \& $25.9 \%$ strongly agreed and believe it is an innovative concept and should be encouraged in the future, $51.9 \%$ agreed, $25 \%$ strongly agreed. Though many agree that e-learning is a time convenient method and allows them to study at their own pace (55 \%, $23.5 \%$ ), fewer believe that e-learning is more comfortable or easy to use than face to face interaction $(35.9 \%$ and $38.2 \%$, respectively, agree).
$34.4 \%$ of respondents strongly agreed, and $46.5 \%$ agreed that e-learning has technical issues of slow or unresponsive internet connectivity. Respondents prefer classroom-based learning to know the identity of instructors, $41.5 \%$. The majority, $35.6 \%$, and $27.1 \%$ answered that their online learning skills and abilities, before starting an e-learning course were assessed only sometimes or rarely. $50 \%$ of the respondents agreed, $15.3 \%$ strongly agreed that e-learning is worth their time, and $49.7 \%$ agreed, $15.9 \%$ strongly agreed that $\mathrm{e}$ - learning is exciting. 
Comparatively, a fewer percentage of participants, $40.9 \%$, agreed that participation and contributions in course activities, consulting provided material, and perceiving progress is better in e-learning than classroom learning. Overall a positive attitude was shown towards e-learning as most of the study participants agreed or strongly agreed to the questions.

\section{Social Presence Based Questions}

In total, seven questions were asked based on social presence in e-learning 15 , depicted in Table 2 . This too, like attitudebased questions, were measured using the 5 point Likert scale. The anchor in the social presence scale was $5=$ strongly agree, $4=$ agree, 3 = not sure, 2 = disagree and $1=$ strongly disagree . $57.4 \%$ agreed, and $23.2 \%$ of the students strongly agreed that the instructor facilitates the discussions in the online classes. They feel more comfortable interacting with others on this platform, $40.9 \%$ (agree), and $17.4 \%$ (strongly agree).

Most of the respondents admit that computer-mediated communication is an excellent medium for social interaction (agree, $47.6 \%$ and strongly agree, $18.5 \%$ ), and the instructor creates a feeling of an online community ( $56.2 \%$ and $18.5 \%$ ). Though the preponderance of the subjects (62.9\%) agree that computer-based presentation becomes impersonal, they believe that their point is better acknowledged (56.1\%) and feel more comfortable in introducing themselves $(64.4 \%)$ here than face to face interaction.

\section{Satisfaction Based Questions}

To measure the satisfaction of the students, nine questions were asked. The questions are shown in Table 3. The overall satisfaction was positive.

The students were satisfied with the support they received from the instructor (60.6\% agree and $21.2 \%$ strongly agree). Majority of them were happy with the online environment, $70.2 \%$, and the learning resources available for them, $72.6 \%$. The quality of delivery of the lectures to attain the interest of the students, and the content and organization of classes is observed to be satisfactory. The respondents were satisfied with the mechanism of assignments in e-learning by $58.2 \%$ and $18.2 \%$.

\begin{tabular}{|c|c|c|c|c|}
\hline & & Attitude & $\begin{array}{c}\text { Social } \\
\text { Presence }\end{array}$ & Satisfaction \\
\hline \multirow[t]{2}{*}{ Attitude } & $\begin{array}{l}\text { Pearson } \\
\text { correlation (r) }\end{array}$ & \multirow[t]{2}{*}{1} & 0.773 & 0.756 \\
\hline & P - Value & & $0.0001^{*}$ & $0.0001^{*}$ \\
\hline \multirow[t]{2}{*}{ Social presence } & $\begin{array}{l}\text { Pearson } \\
\text { correlation (r) }\end{array}$ & 0.773 & \multirow[t]{2}{*}{. } & 0.794 \\
\hline & P - Value & $0.0001^{*}$ & & $0.0001^{*}$ \\
\hline \multirow{2}{*}{ Satisfaction } & $\begin{array}{c}\text { Pearson } \\
\text { correlation (r) }\end{array}$ & 0.756 & 0.794 & \multirow[t]{2}{*}{1} \\
\hline & P - Value & 0.0001* & $0.0001 *$ & \\
\hline \multicolumn{5}{|c|}{$\begin{array}{l}\text { Table 4. Correlation between the Attitude, } \\
\text { Social Presence and Satisfaction of E-learning }\end{array}$} \\
\hline
\end{tabular}

When the three perspectives of e-learning were correlated in Table 4, with each other using Pearson's correlation coefficient, it was found that there was a very strong positive correlation among the three perspectives $(\mathrm{P}=0.0001$ for all three perspectives.)

\section{DISCUSSION}

The sudden onset of the COVID-19 pandemic has resulted in many impediments to the daily lifestyle. One of the major setbacks was the lockdown of schools and universities, which led to the digitalization of the education system. This sudden transition led to many difficulties among the students and the lecturers themselves. Thus, this survey was conducted on the dental students of Faridabad to assess attitude, social presence, and the satisfaction of students with e-learning.

Firaz B et al. a similar survey was conducted on dental students of Iran and Germany, and found that students were having complications in adapting to this unexpected shift.17,18

Santos GN et al. in an analytical study, assessed 11 papers to evaluate the effectiveness of e-learning in oral radiology education. It was observed that technology-based education was well accepted among dental students even before the pandemic, but they prefer the classroom setting over computer-based. Similarly, more than $60 \%$ of the respondents in our study chose the traditional style of teaching over the elearning (Table 1). ${ }^{19}$

The current study shows that students perceive e-learning as a comfortable and a better platform to communicate with lecturers and students. This can be mainly due to the fact that traditional setting are time and place constricted, whereas online classes are not, and the student have a high flexibility. More than $78 \%$ students agreed that e-learning enables them to learn on their own pace. However, in contrast to this result, another study conducted on dental students showed that less than $40 \%$ of the respondents agreed that e-learning provided easier communication with lecturers and colleagues (Table 1). ${ }^{17}$

A study conducted in Iraq shows that, more the technology based skills, higher is the satisfaction of the respondents to elearning. ${ }^{17}$ In our study, it shows that less than $15 \%$ of the respondents have had their online learning skills checked before the onset of online classes. Consequently, lack of skills affected the satisfaction rate of the respondents. This also shows that the majority was not prepared for the transition of conventional environment to online.

A survey was conducted on Chinese nursing students and in a university of Mizoram, it showed that due to lockdown, the students residing in the hostels returned to their homes where the students faced problems like lack of $4 \mathrm{G}$ internet connection or uninterrupted supply of power. Compatibility issues were faced by both the teachers and students. ${ }^{20,21}$ In our study, it shows that more than $80 \%$ respondents complained that they faced technical issues such as slow or uninterrupted internet connection (Table 1).

In contrary to the results found in the present study, where students found e-learning to be exciting, a study conducted in a dental school of Germany shows that the majority of respondents there believe that virtual communication is rather monotonous. ${ }^{18}$ The difference seen might be due to the perception of students, and the teaching environment of the online classes. In a study conducted in 2007 in China, they identified seven factors that shows an impact on the students in online setting which are computer anxiety, instructor attitude, course flexibility, course quality, perceived usefulness, perceived ease of use and diversity of assessment. 
According to this study, the role of instructor is the key factor that influences the e-learner's satisfaction. The effectiveness of the class taken is affected by the instructor's attitude and the strongest influencer of the learner's satisfaction is the course quality. ${ }^{22}$ It is very important for an instructor to compensate for the lack of physical presence and interaction that takes place in a traditional setting, in an online class. This correlation between the instructor and satisfaction of the students explains the high satisfactory levels in our study. The respondents were satisfied by the environment, quality of delivery, the content and organization of the lectures delivered by the instructor. The majority agree that the instructor creates a feeling of online community which facilitates the quality of learning by the students. (Table 2 and 3).

A similar study conducted in Texas, showed that there was rise in student satisfaction as the interaction between the students and instructor support increases. In line to this observation, our study also showed a high rate of instructor support as well as a high satisfactory rate.

In our present study, majority agree that the instructor facilitates the discussions in the online classes, and contribution in activities by the students are better in elearning than in classroom education. This shows that the students think about the topic more and are motivated to ponder on it. However, more than $60 \%$ of the respondents believe that the discussions done online tend to be impersonal, even though their point is better acknowledged in this platform. (Table 2). In contrary to these findings, the study conducted on Iraqi dental students showed that discussions don't play a role in motivating them to study a topic. ${ }^{18}$ Then again, studies show that course dimension and quality play a major role in learner's satisfaction and motivation. ${ }^{22}$ Hence, in both the cases, our study and the study conducted in Iraq, the quality of the course delivery must have influenced the respondents.

A study conducted in Texas on agriculture students showed that students who had positive attitude towards elearning did not prefer the same as their choice of mode of delivery of education, which is in compliance with the results observed in our study. ${ }^{15}$ In compliance to this study, the current study shows an overall positive attitude and satisfaction to technology based education, yet, the preference is given to the traditional setting of classroom.

\section{CONCLUSIONS}

There has been a grave effect on the education system due to the COVID - 19 pandemic. There were major changes to the system, one being the transition from offline to online classroom setting.

The attitude, satisfaction and social presence have been discussed. The survey involved the attitude of the students towards the online education in which the comfort level, communication, and various other aspects of traditional setting and technology-based setting was compared. The results showed a positive response as it was seen in other studies. Though there were few other studies were the results were quiet contradictory to what was seen on this study, the overall satisfaction remained the same among the students. With regards to the social presence, the study shows that the online setting becomes impersonal but the comfort in interaction is better than offline mode. A predominantly positive response was observed for satisfaction aspect.

\section{Limitations}

The study didn't include the lecturer's opinion in this survey. As the lecturers play a major role in the online setting, their opinion had to be considered. Questions concerning the technology-based skills were not asked in this questionnaire as the current generation are well versed and fast to grasp new technological developments.

Data sharing statement provided by the authors is available with the full text of this article at jemds.com.

Financial or other competing interests: None.

Disclosure forms provided by the authors are available with the full text of this article at jemds.com.

\section{REFERENCES}

[1] UNESCO director-general audrey azoulay charts a new strategic direction. UNESCO 2020.

[2] Bao W. COVID-19 and online teaching in higher education: a case study of Pecking University. Wiley Online Library 2020;2(2):113-5.

[3] Devaney J, Shimshon G, Rascoff M, et al. Higher Ed needs a long-term plan for virtual learning. Havard Business Review 2020:2-5.

[4] Liguori EW, Winkler C. From offline to online: challenges and opportunities for entrepreneurship education following the COVID-19 pandemic. Entrepreneurship Education and Pedagogy 2020;3(4):346-51.

[5] Picciano AG. Theories and frameworks for online education: seeking integrated model. Online Learning 2020;21(3):166-90.

[6] Ülker D, Yılmaz Y. Learning management systems and comparison of open source learning management systems and proprietary learning management systems. Journal of Systems Integration 2016;7(2):18-24.

[7] Muilenburg LY, Berge ZL. Student barriers to online learning: a factor analytic study. Distance Educ 2005;26(1):29-48.

[8] Song L, Singleton ES, Hill JR, et al. Improving online learning: Student perceptions of useful and challenging characteristics. Internet and Higher Education 2004;7(1):59-70.

[9] Filius RM, De Kleijn RAM, Uijl SG, et al. Audio peer feedback to promote deep learning in online education. Journal of Computer Assisted Learning 2019;35(5):60719.

[10] Partlow KM, Gibbs WJ. Indicators of constructivist principles in internet-based courses. Journal of Computing in Higher Education 2003;14(2): 68-97.

[11] Anderson T, Rourke L, Garrison DR, et al. Assessing teaching presence in a computer conferencing context. Journal of Asynchronous Learning Networks 2001;5(2):1-17.

[12] Rapanta C, Botturi L, Goodyear P, et al. Online university teaching during and after the Covid-19 crisis: refocusing teacher presence and learning activity. Postdigit Sci Educ 2020:1-23. 
[13] Iyer P, Aziz K, Ojcius DM. Impact of COVID-19 on dental education in the United States. J Dent Educ 2020;84(6):718-22.

[14] Demuyakor J. Coronavirus (COVID-and online learning in higher institutions of education: a survey of the perceptions of ghanaian international students in China. Online Journal of Communication and Media Technologies 2020;10(3):e202018.

[15] Strong R, Irby TL, Wynn J T, et al. Investigating students satisfaction with elearning courses: the effect of learning environment and social presence. Journal of Agricultural Education 2012;53(3):98-110.

[16] Zaheer M, Babar MEE, Gondal UH, et al. E-learning and student satisfaction. Conference: $9^{\text {th }}$ Annual conference of Asian Association of Open Universities (AAOU). Kuala Lumpur, Malaysia, November 2015.

[17] AI-Taweel FB, Abdulkareem AA, Gul SS, et al. Evaluation of technology-based learning by dental students during the pandemic outbreak of coronavirus disease. European Journal of Dental Education 2019;25(1):18390.
[18] Schlenz MA, Schmidt A, Wöstmann B, et al. Students and lecturers perspective on the implementation of online learning in dental education due to SARS-CoV-2 (COVID19): a cross-sectional study. BMC Med Educ 2020;20(1):354.

[19] Santos GNM, Leite AF, De S Figueiredo PT, et al. Effectiveness of E-learning in oral radiology education: a systematic review. J Dent Educ 2016;80(9):1126-39.

[20] Xing W, Ao L, Xiao H, et al. Chinese nurses preferences for and attitudes about e-learning in continuing education: a correlational study. J Contin Educ Nurs 2020;51(2):87-96.

[21] Mishra L, Gupta T, Shree A. Online teaching-learning in higher education during lockdown period of COVID-19 pandemic. International Journal of Educational Research Open 2020;1:100012.

[22] Sun PC, Tsai RJ, Finger G, et al. What drives a successful elearning? An empirical investigation of the critical factors influencing learner satisfaction. Computers \& Education 2007;50(4):1183-202. 